\title{
PENINGKATAN EKSPRESI LAMININ NAMUN TIDAK VE-CADHERIN PADA SAWAR DARAH OTAK SETELAH INFEKSI Mycobacterium tuberculosis INTRAPULMONALIS
}

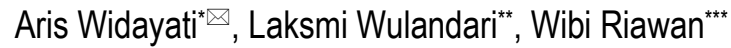

\begin{abstract}
Abstrak
Tuberkulosis merupakan masalah kesehatan utama di dunia. Pada tahun 2016, WHO menemukan angka kejadian TB kurang lebih 10,4 juta, dan untuk Indonesia dilaporkan sebesar 156.723 kasus. Meskipun penyebaran Mycobacterium tuberculosis di susunan saraf pusat tercatat hanya 1\%, namun memiliki tingkat kecacatan dan kematian yang tinggi, sehingga menuntut adanya tatalaksana yang efektif untuk mengatasinya. VE-chaderin dan laminin merupakan protein adhesin yang berfungsi mengendalikan permeabilitas pembuluh darah dan mempertahankan integritas blood brain barrier, sehingga kedua protein adhesin tersebut dapat menjadi salah satu target terapi tuberkulosis otak. Penelitian ini bertujuan untuk mengetahui efek paparan M. tuberculosis secara inhalasi terhadap ekspresi laminin dan VE-chaderin pada sel endotel blood brain barrier. Penelitian ini menggunakan mencit Balb/c (Mus musculus) yang diinfeksi oleh M.tuberculosis strain $\mathrm{H} 37 \mathrm{Rv}$ secara inhalasi. Jaringan otak diperiksa menggunakan metode imunohistokimia dengan antibodi mt-38, antibodi VE-chaderin dan laminin. Hasil penelitian menunjukkan adanya invasi M. tuberculosis pada mikroglia jaringan otak mencit, diiketahui juga adanya peningkatan ekspresi laminin, sedangkan VE-chaderin tidak menunjukkan adanya perubahan. Proses masuknya $M$. tuberculosis ke otak diduga terjadi melalui proses diapedesis atau melalui peningkatan ekspresi laminin tanpa perubahan pada VE-chaderin dan reseptor laminin diduga sebagai tempat berikatan yang memungkinkan bakteri tersebut masuk ke jaringan otak.
\end{abstract}

Kata kunci: Infeksi Mycobacterium tuberculosis, Laminin, VE-chaderin.

\section{INCREASE IN LAMININ EXPRESSION BUT NO VE-CADHERIN IN BRAIN BLOOD BARRIER AFTER INTRAPULMONAL Mycobacterium tuberculosis INFECTION}

\begin{abstract}
Tuberculosis is a major health problem in the world. In 2016, WHO found the incidence of TB around the world is approximately 10.4 million, and in Indonesia was recorded about 156,723 cases. Although Mycobacterium tuberculosis spread to central nerves system only $1 \%$, but it has high morbidity and mortality rate. The high mortality of tuberculosis infection in brain requires an effective management to overcome. VEchaderin and laminin are adhesin protein which control permeability of blood vessels and maintain the integrity of blood brain barrier, that so VE-chaderin and laminin can be one of therapeutic targets for brain tuberculosis case. This study aimed to determine the effect of $M$. tuberculosis exposure on the expression of laminin and VE-chaderin on endothelial blood brain barrier cells. This study used Balb/c mouse (Mus musculus) infected by strain H37Rv of M. tuberculosis by inhalation. Brain tissue was examined using immunochemistry staining with mt-38 antibody, VE-chaderin and laminin antibody. The results indicated the invasion of M. tuberculosis into mouse brain tissue microglia. It was also showed an increase in laminin expression, while VE-chaderin did not show any changes. The process of $M$. tuberculosis entering the brain may occur through the process of diapedesis or through increasing expression of laminin without changes in VE-chaderin, and the laminin receptor is assumed to be a binding site which allows the bacteria to enter the brain tissue.
\end{abstract}

Keywords: Mycobacterium tuberculosis infection, Laminin, VE-chaderin.

* Departemen IImu Faal, Fakultas Kedokteran, Universitas Brawijaya, Malang

** Departemen Ilmu Penyakit Paru, Rumah Sakit Dr.Soetomo, Surabaya

${ }^{* * *}$ Laboratorium Biokimia-Biomolekuler, Fakultas Kedokteran, Universitas Brawijaya, Malang

区E-mail: aris_widayati@yahoo.co.id 


\section{Pendahuluan}

Tuberkulosis merupakan masalah kesehatan utama di dunia. WHO melaporkan bahwa pada tahun 2016 ditemukan insiden TB di dunia adalah 10,4 juta kasus. ${ }^{1}$ Pada tahun 2016, berdasarkan laporan dari Kementerian Kesehatan Republik Indonesia diketahui jumlah kasus baru TB paru adalah 156.723 kasus. ${ }^{2}$. Tuberkulosis seringkali dijumpai di negaranegara berkembang seperti di Asia (59\%) dan Afrika (26\%). Indonesia menduduki urutan ketiga kasus tuberkulosis yaitu sekitar 0,68 juta jiwa. ${ }^{3}$ Indonesia juga tercatat sebagai negara kedua terbesar yang memiliki perbedaan antara kejadian TB dengan kasus yang dilaporkan. ${ }^{1}$ Tuberkulosis pada sistem saraf pusat (SSP) tercatat hanya 1\% dari seluruh kasus tuberkulosis, namun memiliki tingkat morbiditas dan mortalitas yang tinggi. Di Amerika Serikat angka kejadian tuberkulosis pada sistem saraf pusat tercatat $5-10 \%$ dari keseluruhan kasus tuberkulosis ekstrapulmonal. ${ }^{3}$ Tuberkulosis pada sistem saraf pusat merupakan penyakit yang serius dan sering berakibat fatal khususnya pada remaja. Terapi tuberkulosis pada sistem saraf pusat sulit mencapai hasil yang diharapkan. Terapi dengan 4 macam obat HRZE (isoniazid, rifampicin, pyrazinamide, ethambutol) selama 2 bulan dan diikuti dengan pengobatan dengan HR (isoniazid, rifampicin), telah dilakukan sejak 30 tahun yang lalu dan hanya dapat mencegah kematian serta kecacatan pada separuh kasus TB. 4,5

Bakteri penyebab tuberkulosis pada manusia adalah Mycobacterium tuberculosis (M. tuberculosis), yang merupakan bakteri aerob, non motile, non-spore-forming, dan bersifat tahan asam. Penyebaran $M$. tuberculosis diketahui per inhalasi dari droplet nuclei yang banyak mengandung basil tersebut dan menyebabkan bakteri tersebut hidup di alveoli paru. Masuknya $M$. tuberculosis sampai ke alveoli paru akan menimbulkan interaksi dengan makrofag. Infeksi ini menimbulkan rangsangan pada innate immunity cells menghasilkan sejumlah sitokin serta chemokine. Penyebaran secara hematogen akan menyebabkan penyebaran ke organ tubuh lain yang kaya oksigen seperti otak. Karakteristik khusus $M$. tuberculosis adalah kemampuannya untuk masuk dan melakukan replikasi di dalam makrofag (disebut sel mikroglia pada SSP), yang merupakan proses utama invasi bakteri ini pada SSP. 3,6

Blood brain barier (BBB) merupakan barier yang menghubungkan antara darah tepi dengan otak dan berfungsi mengatur keluar masuknya substrat dan bahan metabolit yang diperlukan neuron. Blood brain barier terdiri dari sel endotel, astrocytic end-feet processes dan perisite. Sel endotel otak secara normal saling berhubungan pada junctional complex melalui tight junctions (TJ) dan adherens junctions (AJ). Adherens junction ditemukan saling bercampur dengan tight junction. ${ }^{7}$ Pada kondisi adanya kerusakan pada adheren jucntion maka akan menyebabkan rusaknya BBB. ${ }^{3}$

Pada AJ terdapat protein vascular endothelial (VE) chaderin yang terbentang masuk ke celah interselluler dan terhubung ke sitoplasma sel oleh protein chatenin alpha, gamma dan beta. ${ }^{8}$ Fungsi AJ ini untuk menjaga integritas struktur sel endotel yang diperlukan untuk mengontrol permiabilitas pembuluh darah dan proses perpindahan leukosit ke SSP. 7,8

Vascular endothelial (VE-cadherin) diperlukan untuk mempertahankan kontak antara sel endotel ,sehingga memungkinkan neutrofil dapat keluar dari pembuluh darah secara paraseluler antara sel-sel endotel. ${ }^{9}$ Neutrofil dan monosit yang berada di sirkulasi perifer dapat mengadakan penetrasi ke otak melalui BBB yang rusak terutama 
karena inflamasi. Kemungkinan leukosit dapat melewati BBB setelah terjadi downregulation dari VE-chaderin. ${ }^{8}$

Laminin merupakan komponen utama basal lamina dari BBB. Ekspresi laminin pada pembuluh darah saraf pusat diduga mempunyai peran penting dalam pembentukan BBB dan integritas pembuluh darah di saraf pusat. $^{10}$ Reseptor laminin pada endotel vaskuler banyak berinteraksi dengan virus. ${ }^{11,12}$ Hal ini menunjukkan bahwa reseptor laminin berperan dalam interaksi antara sel - sel yang berbeda maupun dengan sel patogen. ${ }^{13}$

Fungsi lain dari laminin diduga berperan dalam migrasi sel, proliferasi dan diferensiasi berbagai tipe sel. ${ }^{14}$ Vasculer endotelial chaderin dan laminin keduanya berfungsi mengontrol permiabilitas pembuluh darah dan ekstravasasi leukosit serta mempertahankan integritas BBB. ${ }^{10}$ Penelitian ini untuk mengetahui pengaruh paparan $M$. tuberculosis secara inhalasi menggunakan modifikasi Nose Only Inhalation System atau Middle Brook Inhalation Exposure System (Glas-Col) terhadap ekspresi laminin dan VE-chaderin pada sel endotel dari BBB. Hasil penelitian ini diharapkan dapat memberikan wacana baru khususnya dalam memahami patomekanisme terjadinya meningitis atau meningoensepalitis tuberkulosis, dan dapat dikembangkan sebagai salah satu terapi pada kasus infeksi jaringan otak akibat tuberkulosis paru.

\section{Bahan dan Metode}

\section{Rancangan penelitian}

Penelitian ini merupakan penelitian eksperimental dengan desain rancangan acak lengkap, post control study menggunakan mencit (Mus musculus) jenis Balb/c.
Hewan Coba

Mus musculus Balb/c berumur 8-12 minggu, berat badan antara 17-20 gram diperoleh dari PN Biofarma (Persero) Bandung. Selama proses penelitian mencit diperlakukan dalam lingkungan khusus yang bebas patogen sesuai anjuran the Federation of European Laboratoy Animal Science Associations (FELASA). ${ }^{15}$ Penelitian ini telah disetujui dan mendapat sertifikat kelaikan etik dari Komisi Etik (Animal Care and Use Committee) Fakultas Kedokteran Hewan Universitas Airlangga, dengan nomer kelaikan etik 151-KE.

Prosedur Infeksi Mycobacterium tuberculosis Larutan stok bakteri M. tuberculosis strain H37Rv diperoleh dari Kelompok Studi Infeksi Tuberkulosis Lembaga Penyakit Tropis Universitas Airlangga Surabaya. Stok M. tuberculosis H37Rv dilarutkan dalam medium PBS yang mengandung 0,01\% Tween 80. Enam ekor mencit Balb/c dipapar dengan $M$. tuberculosis secara inhalasi menggunakan modifikasi Nose Only Inhalation System atau Middlebrook Inhalation Exposure System (GlasCol). ${ }^{16,17,18}$ Mencit diberi $10 \mathrm{~mL}$ larutan PBSTween 80 yang mengandung $10^{6}$ bacilli secara nebulisasi aerosol selama 30 menit dalam inhalation chamber yang ditempatkan dalam kotak besar berfilter HEPA. Masingmasing mencit dimasukkan ke dalam tabung konikal yang ujung moncongnya menghadap ke dalam ruangan inhalasi yang terhubung dengan pipa nebulizer ultrasonik $\left(\mathrm{Omron}^{\circledR}\right.$ tipe NE-C28, Japan). Semua prosedur tersebut dilakukan pada fasilitas laboratorium yang setara dengan Biosafety Level 3. ${ }^{19}$

\section{Prosedur Pengorbanan Hewan Penelitian \\ Pada hari ke-57 dan hari ke-113 (setelah 8 dan 16 minggu perlakuan) dilakukan pengorbanan masing-masing tiga mencit dengan cara pembiusan}


menggunakan injeksi intramuskuler campuran ketamine $(100 \mathrm{mg} / \mathrm{kg} \mathrm{BB})$ dan xylazine (10 mg/kg BB) pada otot paha. Setelah mencit terbius sempurna, mencit dibaringkan dalam posisi telentang di atas papan deseksi dan keempat ekstremitasnya difiksasi dengan jarum. Pembedahan dilakukan dan setelah rongga dada dibuka, dilakukan drainase darah dari jantung kanan mencit menggunakan spuit dengan jarum 25G. Selanjutnya pembuluh darah paru diperfusi dengan saline-EDTA untuk menyingkirkan semua sel-sel darah yang ada di intravaskuler paru. ${ }^{20}$

\section{Sampel Penelitian}

Pembedahan dilakukan pada regio kepala untuk mengambil jaringan otak. Jaringan difiksasi dengan buffer formalin $4 \%$, kemudian diproses untuk dijadikan preparat. Jaringan didehidrasi menggunakan alkohol bertingkat $(30 \%, 50 \%, 70 \%, 80 \%, 96 \%$ dan absolut) masing-masing 60 menit. Dilakukan clearing menggunakan xilol 2 kali masingmasing 60 menit. Kemudian dilakukan infiltrasi dengan parafin lunak selama 60 menit pada suhu $48^{\circ} \mathrm{C}$. Kemudian dilakukan block dalam parafin keras pada cetakan dan didiamkan selama sehari. Keesokan harinya ditempelkan pada holder dan dipotong setebal $4-6 \mu \mathrm{m}$ dengan rotary microtome. Kemuldian dilekatkan pada gelas objek berpolylisin (PDL). Dari tiap blok paraffin yang dipotong, satu sediaan diwarnai dengan hematoksilin-eosin, sementara satu sediaan lainnya digunakan untuk pewarnaan immunohistokimia.

\section{Pewarnaan Imunohistokimia}

Metode Immunohistokimia dilakukan dengan menggunakan metode streptavidinbiotin-peroksidase yang dilabel dengan streptavidin biotin (Novocastra,USA). Sediaan preparat dilakukan deparafinisasi dengan xylene selama 15 menit dan direhidrasi dengan alkohol $100 \%$ dan $70 \%$ selama masing-masing 10 menit. Sediaan kemudian dicuci dengan $\mathrm{dH}_{2} \mathrm{O}$ sebanyak 2 kali selama 5 menit dan diinkubasi dengan larutan PBS selama 5 menit. Preparat diletakkan ke dalam glass box yang berisi citrate buffer kemudian dimasukkan ke dalam inkubator selama 15 menit untuk mengoptimalkan antigenisitasnya. Sediaan didinginkan pada suhu ruangan selama 1 jam, dan setelah dikeringkan sebentar, jaringan diberi batas dengan menggunakan pap pen. Sediaan dicuci dengan $\mathrm{dH}_{2} \mathrm{O}$ selama 5 menit dan PBS selama 5 menit sebelum diinkubasi dengan $0,3 \% \quad \mathrm{H}_{2} \mathrm{O}_{2}$ selama 15 menit, dibilas dengan PBS pH 7,2 $3 x$ masing-masing selama 5 menit. Lalu, ditambahkan blocking solution dan diinkubasi selama 30 menit. Lakukan inkubasi overnight pada suhu $4{ }^{\circ} \mathrm{C}$ dengan antibodi mt-38\#sc-52104, antibodi Lamininү2 \#sc-28330, dan antibodi VE-Cadherin\#sc9989. Dibilas dengan PBS pH 7,2 3x masing-masing selama 5 menit, inkubasi dengan antibodi sekunder selama 1 jam pada suhu ruang, dan dibilas dengan PBS $\mathrm{pH}$ 7,2 3x masing-masing selama 5 menit. Inkubasi dengan streptavidin-HRP selama 30 menit. Dibilas dengan PBS pH 7,2 3x masing-masing selama 5 menit. Lalu, diteteskan 3,3 diamino benzidine tetrahydrocloride (DAB) dan inkubasi selama 10 menit sampai didapatkan reaksi pewarnaan yang dapat dideteksi dengan pemeriksaan mikroskopis. Lakukan counterstain dengan hematoksilin untuk memperjelas inti sel selama 30 detik dan dicuci dengan air mengalir selama 5 menit. Sediaan diberi malinol sebelum ditutup dengan deck glass. Hasil imunohistokimia, dilakukan penilaian terhadap sitoplasma sel yang berwarna coklat (positif) pada dinding jaringan vaskuler (sel-sel endotel). 
Hasil

Distribusi Mt-38 Mycobacterium tuberculosis Pada Jaringan Otak

Penelitian ini membuktikan adanya infeksi $M$. tuberculosis pada jaringan otak dengan menggunakan antibody spesifik yaitu $\mathrm{mt}-38$. Hasil pewarnaan dengan teknik imunoperoksidase, menunjukkan bahwa pada inhalasi $M$. tuberculosis selama 8 minggu menunjukkan terdapat reaksi positif dengan antibodi $\mathrm{mt}-38$, yang ditandai adanya warna coklat gelap pada sel-sel microglia jaringan otak. Reaksi positif ini tampak meningkat pada kelompok inhalasi selama 16 minggu (Gambar 1).

Hal ini mengindikasikan bahwa induksi intrapulmonal $M$. tuberculosis selama 8 minggu dapat menyebabkan aktivasi receptor microglia jaringan otak. Induksi patogen $M$. tuberculosis selama 16 minggu mengaktivasi microglia jaringan otak yang ditandai dengan peningkatan ukuran sel-sel mikroglia.

Distribusi Laminin dan VE-Chaderin pada Blood Brain Barier

Hasil pemeriksaan menggunakan antibodi mt-38 pada mencit yang diinhalasi

bakteri $M$. tuberculosis menunjukan keberadaan $M$. tuberculosis pada jaringan otak. Penelitian ini juga menguji peran laminin- $\gamma 2$ blood brain barrier dalam meregulasi masuknya $M$. tuberculosis pada jaringan otak. Pada Gambar 2, menunjukkan distribusi laminin (tanda panah) meningkat seiring dengan lama waktu inkubasi hewan coba yang ditandai dengan peningkatan intensitas warna coklat pada area vaskuler (sel endotel). Namun demikian, distribusi VEcadherin (tanda panah) area pembuluh darah otak, yang diamati pada area yang sama, menunjukkan tidak terdapat peningkatan intensitas warna coklat. Hal ini menunjukkan bahwa tidak terjadi peningkatan ekspresi VE-cadherin blood brain barrier setelah masa inkubasi hewan model yang diinhalasi $M$. tuberculosis. Jadi, bisa dinyatakan bahwa laminin kemungkinan terlibat dalam mekanisme masuknya $M$. tuberculosis. Tidak adanya penurunan ekspresi VE-cadherin, menunjukkan tidak adanya kerusakan pada sistem vaskuler otak

Kontrol

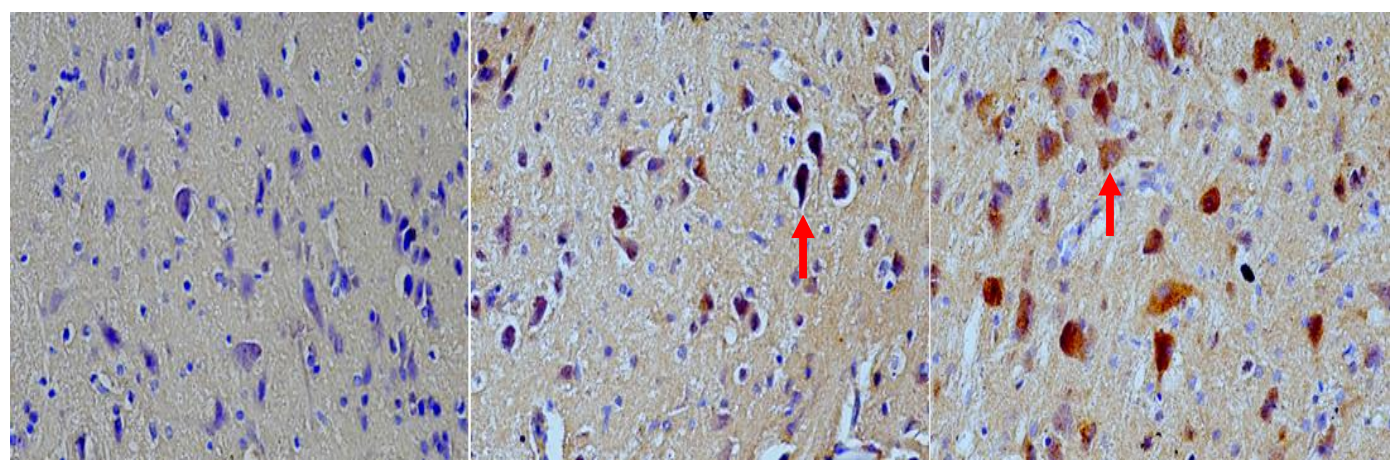

Gambar 1. Distribusi mt-38 M. tuberculosis pada mikroglia jaringan otak tikus yang diinduksi H37Rv intrapulmonal, dengan pengecatan imunohistokimia (perbesaran 400x). Tanda panah merah menunjukkan sel-sel microglia dengan reaksi positif terhadap mt-38 yang berwarna coklat tua. Tampak terdapat peningkatan distribusi mt-38 sel-sel mikroglia jaringan otak mencit yang mendapatkan induksi M. tuberculosis, seiring dengan masa inkubasi infeksi. 


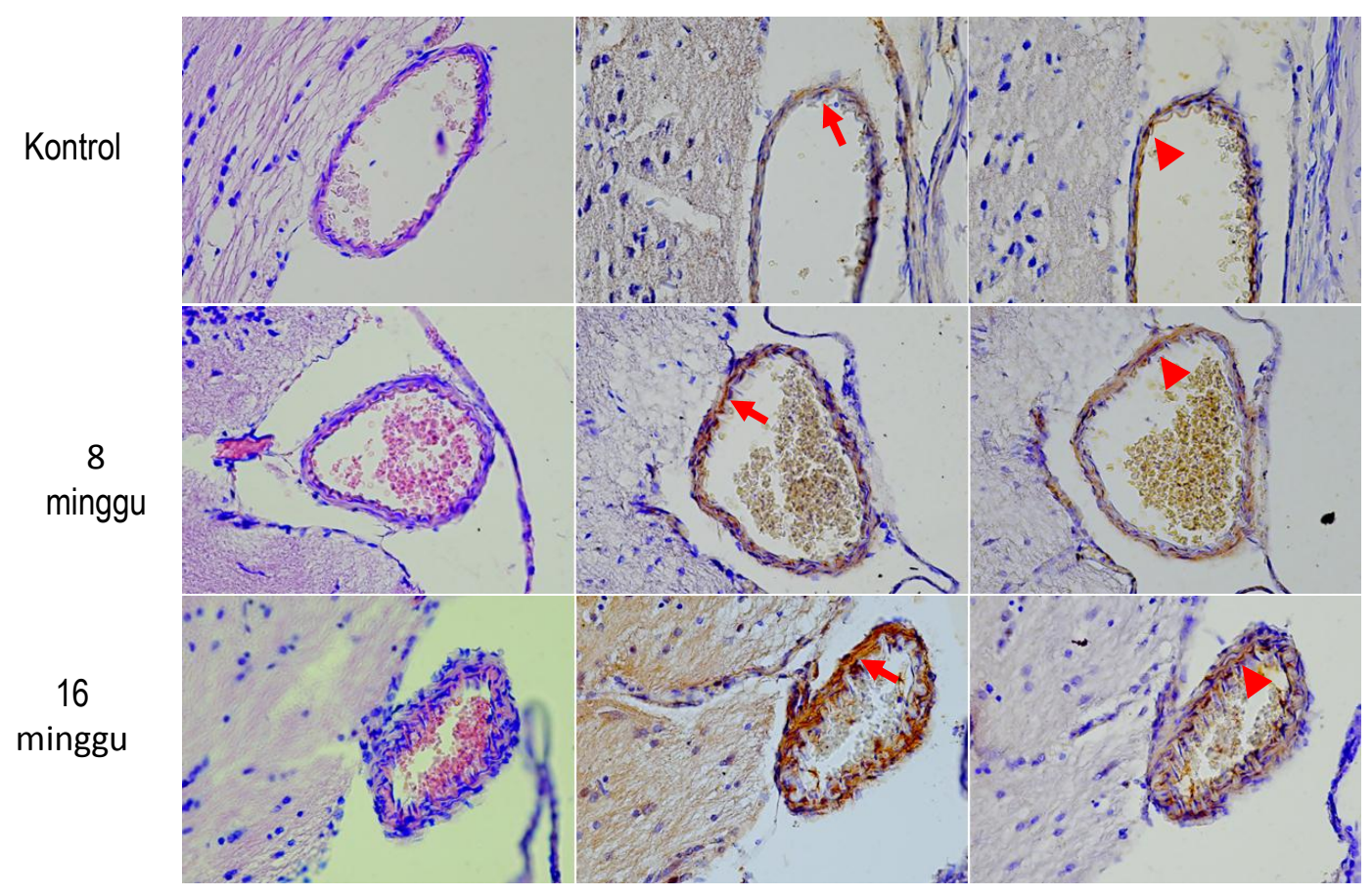

Gambar 2. Photomicrograph blood brain barier (BBB) dengan pewarnaan Hematoxylen-Eosin yang menunjukkan ekspresi laminin- $\gamma 2$ serta VE-cadherin pada jaringan otak dengan infeksi $\mathrm{H} 37 \mathrm{Rv}$ intrapulmonal selama 8 dan 16 minggu ditunjukkan peningkatan intensitas warna coklat pada area vaskuler (sel endotel) (panah merah) (perbesaran 200x).

\section{Pembahasan}

Blood brain barier (BBB) merupakan barier yang berfungsi menjaga stabilitas lingkungan di otak. BBB ini utamanya terdiri dari microvascular endhotelial yang sangat kuat. Bagian basal endhotelial ini disusun oleh astrocyte dan saling bertautan dengan matriks ekstraseluler. Transportasi substansi di otak secara paraseluler dibatasi oleh keberadaan endhotelial tight junction, sedangkan transpor trans-seluler dibatasi oleh relatif sedikitnya vesikel endocytosis. Oleh karena itu, BBB ini sangat selektif terhadap berbagai substansi, dan tidak semua substansi dapat melewatinya. Proteksi central nervous system (CNS) ini juga diperankan oleh cerebrospinal fluid (CSF), yaitu adanya pemisahan sirkulasi cairan otak terhadap plexus coroideus. Batas sel antara darah dan CSF ini memiliki efek seperti BBB, yaitu lebih memperketat proses transitosis. ${ }^{13}$

Berkaitan dengan pengaturan pergerakan sel imun, diketahui bahwa leukosit, monosit dan makrofag dapat masuk ke SSP pada kondisi patologis. Penyebaran M. tuberculosis dari sistem darah perifer diduga melalui proses invasi dari mkroglia yang terinfeksi oleh M. tuberculosis. Bakteri M. tuberculosis diketahui memiliki kemampuan untuk mengadakan replikasi di dalam makrofag ataupun mikroglia. Seperti yang telah banyak diketahui bahwa sel imun mampu mengadakan penetrasi ke jaringan 
otak jika didapatkan kondisi patologis yang merusak BBB, seperti adanya proses inflamasi.

Hasil penelitian ini menunjukkan bahwa proses penyebaran bakteri $M$. tuberculosis ke sistem saraf pusat diduga tidak melibatkan disfungsi protein adhesin VEchaderin. Hasil pengecatan imunohistokimia VE-chaderin yang berfungsi menjaga integritas BBB tidak menunjukkan perubahan ekspresi. Pada umumnya VE-chaderin akan mengalami perubahan berupa downregulation agar dapat dilewati oleh leukosit yang menuju jaringan otak. Namun Joan, et al, menyebutkan bahwa pada kondisi BBB normal atau intact maka leukosit dapat melewatinya melalui proses diapedesis yaitu proses masuknya sel secara langsung melalui sitoplasma endothel dan tidak melalui celah antar sel yang memerlukan pembukaan tight junction. Mekanisme ini memungkinkan sel mononuklear melintasi BBB tanpa adanya kerusakan tight junction. ${ }^{21}$ Jadi, diduga ada kemungkinan bakteri TB mengadakan penetrasi ke jaringan otak melalui diapedesis mikroglia, yaitu masuknya sel mikroglia yang terinfeksi bakteri secara transeluler tanpa perlu perubahan dari VE-chaderin, sehingga terjadi ekstravasasi sel imun dari sirkulasi menuju jaringan. Tanpa adanya perubahan VE-chaderin pada BBB, tidak dapat disimpulkan bahwa BBB tidak mengalami perubahan, karena VE-chaderin hanya salah satu protein penyusun BBB. Protein lain masih sangat mungkin berperan dan mungkin mengalami perubahan saat ada kondisi patologis pada jaringan otak.

Sementara itu, laminin yang merupakan komponen utama basal membran menunjukkan hasil berupa upregulation. Laminin memiliki fungsi hampir sama dengan VE-chaderin yaitu menjaga integritas BBB. Upregulation laminin kemungkinan juga menjadi mekanisme masuknya kuman TB ke dalam otak selain proses diapedesis. Sesuai dengan penelitian yang dilakukan oleh Orihuela yang menunjukkan bahwa reseptor laminin, khususnya gugus carboxyl, pada ujung reseptornya merupakan tempat perlekatan dengan molekul adhesi bakteri. ${ }^{22}$ Aktifasi pada reseptor laminin ini akan menyebabkan ikatan LR (laminin reseptor) dengan bakteri patogen, sehingga memungkinkan bakteri masuk kejaringan otak. Peningkatan ekspresi laminin pada BBB diduga dapat meningkatkan aktivasi ikatan reseptor laminin terhadap bakteri patogen, yang memungkinkan bakteri dapat masuk ke jaringan otak melalui BBB.

\section{Kesimpulan}

Mekanisme penyebaran bakteri TB dari perifer ke jaringan otak dapat melalui beberapa proses. Salah satu mekanisme masuknya bakteri $M$. tuberculosis diduga melalui reseptor laminin pada gugus akhir karboksil, sehingga bakteri dapat masuk dari sistem darah tepi ke jaringan otak. Mekanisme lain diduga melalui proses diapedesis, yaitu mikroglia yang terinfeksi $M$. tuberculosis masuk ke otak secara langsung melalui transeluler dan kemungkinan tidak melibatkan perubahan VE-chaderin pada blood brain barrier (BBB).

\section{Saran}

Perlu dilakukan penelitian lebih lanjut mengenai patomekanisme masuknya bakteri M. tuberculosis ke SSP.

\section{Daftar Pustaka}

1. World Health Organization (WHO).Global Tuberculosis Report. Geneva. 2017.

2. Kementrian Kesehatan RI. Data dan Informasi Profil Kesehatan Indonesia 2016. Boga Hardhana dkk (Editor). 
Jakarta: Pusat Data dan informasi Kementerian Kesehatan RI. 2017

3. Rock RB, Olin M, Baker CA, Molitor TW, and Peterson PK. Central Nervous System Tuberculosis: Pathogenesis and Clinical Aspects. Clinical Microbiology Reviews. 2008;21:243-361.

4. Jacobs RF, Starke JR. Mycobacterium tuberculosis. In: Long SS, Pickering, LK,Prober CG (Editors). Principles and Practice of Pediatric Infectious Diseases. New York: Churchill Livingstone.2003.

5. Jain SK, Kwon P, Moss WJ. Management and Outcomes of Intracranial Tuberculomas Developing During Antituberculous Therapy: Case Report and Review. Clin Pediatr. 2005; 44:443-450.

6. Banks WA and Erickson MA. The BloodBrain Barrier and Immune Function and Dysfunction. Neurobiology of Disease. 2010; (37):13 - 25.

7. Zlokovic BV. The Blood-Brain Barrier in Health and Chronic Neurodegenerative Disorders. J Neuron. 2008; (57):178-201.

8. VestweberDet al. Cell Adhesion Dynamics at Endothelialjunctions: VECadherin as A Major Player. $J$ cell biol. 2008; (19):8-15.

9. Gotsch U,Borge E, Bosse R, Simon M, Mossmann H, Vestweber D. VE-Cadherin Antibody Accelerates Neutrophil Recruitment In Vivo. Journal of Cell Science.1997; 110:583-588.

10. Almutairi MMA, Gong $C, X u Y G$, Chang $Y$, Shi $H$. Factors Controlling Permeability of The Blood-Brain Barrier. Cell Mol Life Sci. 2016; 73:57-77.

11. ThepparitC and Smith D. SerotypeSpecific Entry of Dengue Virus into Liver Cells: Identification of the $37 \mathrm{kDa} / 67$ kDaHigh Affinity Laminin Receptor as a Dengue Virus Serotype 1 Receptor. JVirol. 2004; 78:12647-12656.
12. Akache, B, Grimm D, Pandey K, Yant S,Zu H, and Kay M. The 37/67 KiloDalton Laminin Receptor is a Receptor for Adeno-Associated Virus Serotypes 8,2,3, and 9. J Virol. 2006;80:9831-9836.

13. Orihuela CJ,Mahdavi J,Thornton J,Mann B,Wooldridge KG,Abouseada N,Oldfield NJ, Self T, Ala'Aldeen DAA,Tuomanen El.LamininReceptor Initiates Bacterial Contact with The Blood Brain Barrier in Experimental Meningitis Models. The Journal of Clinical Investigation. 2009; 119(6):1638-164.

14. Sixt $M$ et al.Endothelial Cell Laminin Isoforms, Laminins 8 and 10, Play Decisive Roles in T Cell Recruitment Across The Blood-Brain Barrier in Experimental Autoimmune. Encephalomyelitis.J Cell biol. 2001; 153(5):933 - 945.

15. Nicklas W, BaneuxP,Boot $R$, Decelle $T$ ,Deeny AA, Fumanelli M, Ilgen-Wickle $B$. Recommendations for the Health Monitoring of Rodent and Rabbit Colonies in Breeding and Experimental Units. Lab Animal. 2002; 36:20-42.

16. Mac Farland HN. Designs and Operational Characteristics of Inhalation Exposure Equipment - A Review.Fund Appl Toxicol.1983; 3:603-613.

17. Smith D, Wiegeshaus E, Balasubramanian V. Animal Model for Experimental Tuberculosis. Clin Infect. 2000; 31(3):S68- S70.

18. Denker ND,Scelig DM, Telling GC, Hoover EA. Aerosol and Nasal Transmission of Chronic Wasting Diseases in Cervidized Mice. J Gen Virol. 2010; 91:1651- 1658.

19. Orme IM and Robert AD.Animal Models of Mycobacteria Infection. Curr Protocols Immunol. 1999; 2:499-511.

20. Moerloose KB et al. Cigaratte Smoke Exposure Facilitats Allergic Sensitization in Mice . Respir Res. 2006; 7:49. 
21. Joan $A N$ et al. Structure and Function of The Blood-Brain Barrier. Neurobiology of Disease. 2010; 37:13-25.
22. Be NA, Kim KS, Bishai.W, Jain SK. Pathogenesis of Central Nervus System Tuberculosis. Curr Mol Med. 2009; 9(2):94-99. 